The Response of Seed Germination and Seedling Growth Of Papaya (Carica papaya L.)

CV CALINA to The Concentration Treatments and The Duration of Seed Soaked In

\title{
Coconut Water
}

Agus Zainudin ${ }^{1 *}$ and Almas Adlina Adini'

1), 2), Agrotechnology Department, Faculty of Agriculture and Animal Science, University of Muhammadiyah Malang, Malang, 65144, Indonesia

${ }^{*}$ Corresponding Author: aguszainudinumm@gmail.com

\begin{abstract}
This research aimed to carry out the response of seed germination and seedling growth of Calina papaya to the seed soaked in coconut water. It was conducted from April to June 2017. The study comprised two designs of experiment i.e. the Completely Randomized Design for the seed germination and the Randomized Complete Block Design for the seedling growth of papaya. There were 25 treatment combinations obtained and each treatment was replicated three times. The treatment factors comprised the concentration and the duration of seed soaked in coconut water. The results showed that the seed immersion in the $80 \%$ concentration of coconut water for 8 hours had the highest growth rate and vigour index. Meanwhile, the seed immersion in the $60 \%$ concentration of coconut water for 8 hours showed the highest percentage of germination. The seed immersion for eight hours resulted in the seedling growth of papaya.
\end{abstract}

Keywords: Papaya Seeds, Coconut Water, Viability, Growth of Plant

\section{Introduction}

The production of Papaya for the past few years since 2011 till 2015 has fluctuated with the results of the highest of the national production in 2011 (958.251 tons), but the production of papaya declining until the end of 2015 (851.532 ton) (Directorate General of Horticulture, 2016). Even though the production of papaya is quite high, but it's can not cover the consumption needs that reached 2,243 kg/capita/year in 2015 (Statistic Indonesia, 2015).

The development of papaya required sustainable seeds. The availability of the seeds with the quality and vigorous seedling becomes the priorities for papaya nursery growers. The problems faced in growing papaya is because the long process of germinating seeds if there is no pre-treatment for the seeds and they cannot germinate at the same times, so that caused the seeds can not growing uniform. The emergence of seeds papaya generally completed in 2-3 weeks. Papaya seed is enclosed within a gelatinous sarcotesta which made a long process for seed germination. The sarcotesta itself containing phenolic compounds (Victor et al., 2014).

Pre-sowing treatment of papaya seeds needs to be done to improve germination. KNO3 generally used for breaking dormancy of seeds, developing of seedling pre-soaked by $\mathrm{KNO} 3$ can increase the presentation of germinating than seed without soaking in $\mathrm{KNO} 3$ (Nishina et al., 2004). Lay (2015) reported that immersion seed papaya with GA3 at concentration $300 \mathrm{ppm}$ for 12 hours can improve germination until $93 \%$ compare to control that only $64 \%$.

Coconut water containing several active substance and Phytohormone that required by the seeds to germinate. Growth regulators that found in coconut water such as auxin, gibberellin, cytokinin, pyridoxine, nicotinic acid and thiamine (Kende, 1977). Matsushima and Sakagami (2013) said that soaking seed is invigorated methods to accelerate germinating and produce vigorous seeds. Soaking seeds in coconut water can improve the percentage of 
germination, this is because immersion in coconut water can activatable cell metabolism and influential the growth of early plants.

Therefore, the present study was initiated to find out seed germination and seedling growth of papaya cv. Calina treated by concentration and duration of immersion with coconut water.

\section{Material and Method}

The experiment was conducted from AprilJune 2017 at Malang, East Java. The materials and method for experiment 1 are thermometer, plastic container, fabric, light bulb 60 watt and 10 watt, plastic cups, hand sprayer, measuring cup, papaya seeds cv. Calina, young coconut water, water, paper, and a black plastic bag.

The materials and method for experiment II are analytical scales, polybag $(10 \times 20 \mathrm{~cm})$, label, stationary, camera, oven, sprayer, hoe, scoop, bucket, sand, manure, soil, husk, plastic, oven paper, Gandasil D, insecticide with active ingredient tiamoteksam, fungicide with active ingredient benomyl, and aluminium foil.

The study comprised two designs of experiment i.e. the Completely Randomized Design for the seed germination and the Randomized Complete Block Design for the seedling

Table 1. Effect of concentration and pre-soaking seed on coconut water on days to plumule appearance, height of hypocotyl, seed germination, vigour index.

\begin{tabular}{lllll}
\hline Treatments & $\begin{array}{l}\text { Days to } \\
\text { plumule } \\
\text { appearance }\end{array}$ & $\begin{array}{l}\text { Height of } \\
\text { hypocotyl } \\
(\mathrm{cm})\end{array}$ & $\begin{array}{l}\text { Seed } \\
\text { germination (\%) }\end{array}$ & $\begin{array}{l}\text { Vigour index } \\
\text { tr } \%)\end{array}$ \\
\hline $\begin{array}{l}\text { The concentration of coconut } \\
\text { water (\%) }\end{array}$ & & & & \\
20 & $18.4 \mathrm{a}$ & $1.9 \mathrm{a}$ & $28.0 \mathrm{~b}$ & $6.0 \mathrm{~b}$ \\
40 & $16.6 \mathrm{a}$ & $1.7 \mathrm{a}$ & $31.3 \mathrm{~b}$ & $14.0 \mathrm{ab}$ \\
60 & $17.1 \mathrm{a}$ & $1.9 \mathrm{a}$ & $44.7 \mathrm{a}$ & $14.7 \mathrm{ab}$ \\
80 & $16.7 \mathrm{a}$ & $1.9 \mathrm{a}$ & $42.0 \mathrm{a}$ & $16.7 \mathrm{ab}$ \\
100 & $16.5 \mathrm{a}$ & $1.8 \mathrm{a}$ & $43.3 \mathrm{a}$ & $19.3 \mathrm{a}$ \\
\hline Duration of seed immersion & & & & \\
(hours) & & & & \\
8 & $17.1 \mathrm{a}$ & $1.8 \mathrm{a}$ & $84.0 \mathrm{a}$ & $39.3 \mathrm{a}$ \\
12 & $16.9 \mathrm{a}$ & $1.9 \mathrm{a}$ & $36.0 \mathrm{~b}$ & $9.3 \mathrm{~b}$ \\
16 & $16.1 \mathrm{a}$ & $1.8 \mathrm{a}$ & $28.0 \mathrm{bc}$ & $11.3 \mathrm{~b}$ \\
20 & $17.0 \mathrm{a}$ & $1.9 \mathrm{a}$ & $22.0 \mathrm{c}$ & $6.7 \mathrm{~b}$ \\
24 & $18.4 \mathrm{a}$ & $1.9 \mathrm{a}$ & $19.33 \mathrm{c}$ & $4.0 \mathrm{~b}$ \\
\hline
\end{tabular}

growth of papaya. There were 25 treatment combinations obtained and each treatment was replicated three times. The treatment factors comprised the concentration; $20 \%$ coconut water, $40 \%$ coconut water, $60 \%$ coconut water, $80 \%$ coconut water, $100 \%$ coconut water and the duration of seed immersion in coconut water; 8 hours, 12 hours, 16 hours, 20 hours and 24 hours.

Observations were recorded in days to plumule appearance, seed germination $(\%)$, vigour index (\%), speed of emergence $(\%)$, height of hypocotyl $(\mathrm{cm})$, height of plant $(\mathrm{cm})$, diameter of the stem $(\mathrm{cm})$, number of leaves per plant, fresh weight of sooth (g), fresh weight of root $(\mathrm{g})$, dry weight of sooth $(\mathrm{g})$, dry weight of roots $(\mathrm{g})$, total dry weight $(\mathrm{g})$.

The recorded data were analyzed statistically using $\mathrm{F}$ test at $1 \%$ and $5 \%$ level, if shown real results followed by Duncan Multiple Range Test (DMRT) at 5\% level. Quantitive data analysis using SAS version 9.2.

\section{Results and Discussions}

\section{Experiment I}

The seeds germination parameters of papaya as affected by concentration and pre-soaking on coconut water are presented in Table 1.

$\mathrm{tr}=$ data transformation using $\sqrt{ }(\mathrm{X}+0.5$ 

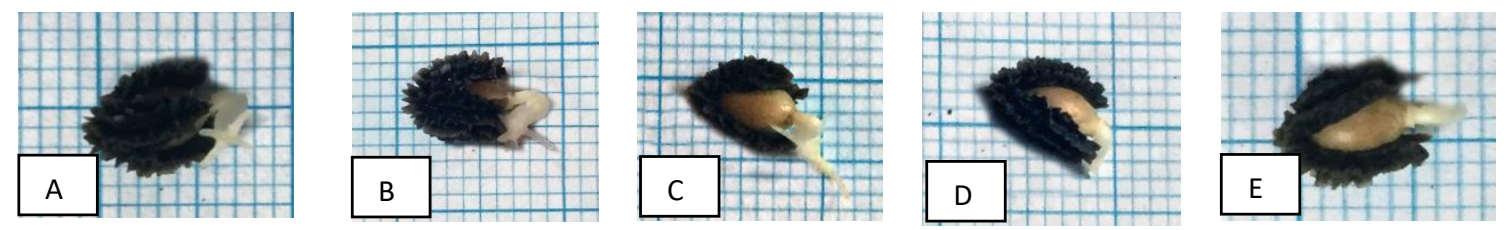

Fig 1. Plumule appearance A) Papaya seed K1T1, B) papaya seed K2T1, C) papaya seed K3T1, D) papaya seed K4T1, E) papaya seed K5T1

Concentration of $100 \%$ coconut water with 16 hours pre-soaking had taken less number of days for appearance plumule (16.5 and 16.1 days). The highest germination (84\%) was recorded at 8 hours pre-soaking and $(44.7 \%)$ was recorded on concentration of $60 \%$ coconut water. The highest vigour index (19.3\%) was recorded at $100 \%$ concentration of coconut water and 8 hours pre-soaking (39.3\%). The result was attained due to the contain of fitohormon in coconut water such as gibberellins acts on the embryo and causes synthesis of hydrolysing enzymes particularly amylase and protease and this hydrolysed food is utilized for grown of the embryo and thereby enhanced the germination (Paleg, 1965).

The speed emergence of papaya seed as affected by concentration and pre-soaking on coconut water presented in Table 2. Faster protrusion of radicle has found in the concentration of $80 \%$ coconut water and 8 hours pre-soaking $(6.3 \% /$ days $)$ as compared to concentration of $60 \%$ coconut water in 24 hours pre-soaking $(0.75 \% /$ days $)$ that has the low value. Soaking seeds on coconut water at 24 hours at room temperature caused fermentation and the chemical reaction that affect on seeds structure, that's caused inhibition on seed germination.

Table 2. Effect of concentration and pre-soaking seed on coconut water on speed emergence of seeds

\begin{tabular}{|c|c|c|c|c|c|}
\hline \multirow{3}{*}{ Concentration (\%) } & \multicolumn{5}{|c|}{ Duration of Immersion (Jam) } \\
\hline & 8 & 12 & 16 & 20 & 24 \\
\hline & \multicolumn{5}{|c|}{ Speed Emergence (\%/days) } \\
\hline 20 & $3.9 \mathrm{bcd}$ & $1.2 \mathrm{fg}$ & $1.1 \mathrm{fg}$ & $0.8 \mathrm{~g}$ & $1.01 \mathrm{~g}$ \\
\hline 40 & $5.1 \mathrm{~b}$ & $0.9 \mathrm{~g}$ & 1.9 efg & $1.4 \mathrm{efg}$ & $0.9 \mathrm{~g}$ \\
\hline 60 & $5.2 \mathrm{ab}$ & $4.3 b c$ & $1.8 \mathrm{efg}$ & $1.7 \mathrm{efg}$ & $0.75 \mathrm{~g}$ \\
\hline 80 & $6.3 a$ & 2.7 ef & $1.4 \mathrm{efg}$ & $1.4 \mathrm{efg}$ & $0.95 \mathrm{~g}$ \\
\hline 100 & $5.4 a b$ & 2efg & $2.8 \mathrm{cde}$ & $1.8 \mathrm{efg}$ & 1.7 efg \\
\hline
\end{tabular}

The concentration of coconut water and the duration of seed immertion had an influence on seeds viability and vigorous. The statement according to Shahi et al (2012) that said one of pre-treatment on the seeds aims to break dormancy and resulting in uniform seeds growth, one of the efforts is pre-soaking.

Seed soaked in coconut water had a significant effect on seed viability and vigour it might be due to the coconut water that contain several active compounds such as mineral, carbohydrate and protein. During the process of germination, the seeds which not yet able to photosynthesis use food reserve in the embryo. By soaked in coconut water, the seeds get additional supply of carbohydrates so the seeds has great energy that caused quickly germinate.
The results that presented in Table 1 and 2 shows that the seed soaked with coconut water for 24 hours indicate the lowest viability. According to Desai et al (2017) if the food reserves available but in less amount can caused weak plant growth, despite of that the longer duration of immersion cannot increase the ability of seeds germination. Seeds that are too long soaked will caused lack of oxygen that makes the seed difficult to germinate. The germination process can inhibit if the use of oxygen is inhibited (Ramteke et al, 2015).

\subsection{Experiment II}

The growth parameters of papaya as affected by concentration and duration of immersion on coconut water are presented in Table $(3,4,5$, and 6). The plant height is one of the important 
characters in growth and development of seeding. At 35 DAS seeds treated by soaking on coconut water at 8 hours recorded highest high height $(18.1 \mathrm{~cm})$, and at 42 DAS seeds treated by concentration of coconut water at 24 hours $(21.2 \mathrm{~cm})$. Phytohormon in coconut water such as auxin and cytoknin can increased cell division and cell elongation which increased the germination and overall growth of the seedlings which caused higher plant growth. Auxin will helped cell differentiation and develop into shoot and stem Olajide et al, 2014).

Despite of growth regulators hormone, coconut water also contain nutritional elements such as $\mathrm{K}$ (Potassium) and CA (Calcium). The element of Potassium useful to stimulate the growth of the plant while Calcium useful for cell division and elongation, by the process of cell division and elongation then the plant will grow higher (Pandit et al, 2001).

Table 3. Mean performance of plant height influenced by concentration and duration of seed immersion

\begin{tabular}{lcccccc}
\hline Treatment & 7 & \multicolumn{5}{c}{ Plant of Height (cm) (DAS) } \\
& & 14 & 21 & 28 & 35 & 42 \\
\hline Concentration (\%) & & & & & & \\
20 & $5.9 \mathrm{a}$ & $8.4 \mathrm{a}$ & $12.1 \mathrm{a}$ & $14.3 \mathrm{a}$ & $16.1 \mathrm{a}$ & $19.4 \mathrm{a}$ \\
40 & $5.7 \mathrm{a}$ & $8.8 \mathrm{a}$ & $12.5 \mathrm{a}$ & $14.7 \mathrm{a}$ & $16.4 \mathrm{a}$ & $19.5 \mathrm{a}$ \\
60 & $5.8 \mathrm{a}$ & $8.7 \mathrm{a}$ & $12.1 \mathrm{a}$ & $14.5 \mathrm{a}$ & $16.4 \mathrm{a}$ & $19.4 \mathrm{a}$ \\
80 & $5.8 \mathrm{a}$ & $8.9 \mathrm{a}$ & $12.5 \mathrm{a}$ & $14.9 \mathrm{a}$ & $16.9 \mathrm{a}$ & $19.9 \mathrm{a}$ \\
100 & $5.9 \mathrm{a}$ & $9.1 \mathrm{a}$ & $12.4 \mathrm{a}$ & $14.8 \mathrm{a}$ & $17.1 \mathrm{a}$ & $18.9 \mathrm{a}$ \\
\hline Duration of & & & & & & \\
immersion (hours) & & & & & & \\
8 & $5.7 \mathrm{a}$ & $8.7 \mathrm{a}$ & $12.5 \mathrm{a}$ & $15.6 \mathrm{a}$ & $18.1 \mathrm{a}$ & $18.4 \mathrm{~b}$ \\
12 & $5.8 \mathrm{a}$ & $8.9 \mathrm{a}$ & $12.4 \mathrm{a}$ & $14.4 \mathrm{a}$ & $15.7 \mathrm{~b}$ & $21.1 \mathrm{a}$ \\
16 & $5.7 \mathrm{a}$ & $8.4 \mathrm{a}$ & $11.8 \mathrm{a}$ & $14.1 \mathrm{a}$ & $15.9 \mathrm{~b}$ & $17.3 \mathrm{~b}$ \\
20 & $6.2 \mathrm{a}$ & $9.5 \mathrm{a}$ & $12.6 \mathrm{a}$ & $14.7 \mathrm{a}$ & $16.5 \mathrm{ab}$ & $19.1 \mathrm{ab}$ \\
24 & $5.7 \mathrm{a}$ & $8.4 \mathrm{a}$ & $12.2 \mathrm{a}$ & $14.5 \mathrm{a}$ & $16.6 \mathrm{ab}$ & $21.2 \mathrm{a}$ \\
\hline
\end{tabular}

\section{DAS: Days after sowing}

The number of leaves per plant presented in Table 4. From the physiological point of view, leaf is the most important photosynthetic site of the plant derives energy for its metabolic activities (Parab et al, 2017). Regarding the number of leaves, at 42 DAS for the seeds that threated by pre soaking 8 hours on coconut water was recorded that has more leaves per plant (7) compare to others treatment.

Table 4. Mean performance of number of leaves per plant influenced by concentration and duration of seed immersion

\begin{tabular}{lllllll}
\hline Treatment & \multicolumn{7}{c}{ Number of leaves per plant (DAS) } \\
& $7^{\text {tr }}$ & 14 & 21 & 28 & 35 & 42 \\
\hline Concentration (\%) & & & & & & \\
20 & $1.1 \mathrm{a}$ & $2.5 \mathrm{a}$ & $4.3 \mathrm{a}$ & $5.6 \mathrm{a}$ & $6.2 \mathrm{a}$ & $6.4 \mathrm{a}$ \\
40 & $0.98 \mathrm{a}$ & $2.6 \mathrm{a}$ & $4.0 \mathrm{a}$ & $5.5 \mathrm{a}$ & $6.3 \mathrm{a}$ & $6.1 \mathrm{a}$ \\
60 & $1.2 \mathrm{a}$ & $2.5 \mathrm{a}$ & $4.3 \mathrm{a}$ & $5.8 \mathrm{a}$ & $6.5 \mathrm{a}$ & $6.1 \mathrm{a}$ \\
80 & $0.96 \mathrm{a}$ & $2.4 \mathrm{a}$ & $4.3 \mathrm{a}$ & $6.1 \mathrm{a}$ & $6.7 \mathrm{a}$ & $6.4 \mathrm{a}$ \\
100 & $0.94 \mathrm{a}$ & $2.5 \mathrm{a}$ & $4.1 \mathrm{a}$ & $5.6 \mathrm{a}$ & $6.4 \mathrm{a}$ & $5.7 \mathrm{a}$ \\
\hline Duration of immersion & & & & & & \\
(hours) & & & & & & \\
8 & $1.04 \mathrm{a}$ & $2.5 \mathrm{a}$ & $4.2 \mathrm{a}$ & $6.1 \mathrm{a}$ & $6.8 \mathrm{a}$ & $6.9 \mathrm{a}$ \\
12 & $1.03 \mathrm{a}$ & $2.7 \mathrm{a}$ & $4.3 \mathrm{a}$ & $5.6 \mathrm{ab}$ & $6.4 \mathrm{a}$ & $5.9 \mathrm{a}$ \\
16 & $1.0 \mathrm{a}$ & $2.3 \mathrm{a}$ & $4.1 \mathrm{a}$ & $5.4 \mathrm{~b}$ & $6.3 \mathrm{a}$ & $5.9 \mathrm{a}$ \\
20 & $1.1 \mathrm{a}$ & $2.6 \mathrm{a}$ & $4.3 \mathrm{a}$ & $5.6 \mathrm{ab}$ & $6.3 \mathrm{a}$ & $5.7 \mathrm{a}$ \\
24 & $0.9 \mathrm{a}$ & $2.4 \mathrm{a}$ & $4.2 \mathrm{a}$ & $6.1 \mathrm{a}$ & $6.2 \mathrm{a}$ & $6.3 \mathrm{a}$ \\
\hline
\end{tabular}

Tr: data transformation with $\log (\mathrm{X}+1)$; DAS: Days after sowing

Girth of the stem was presented on Table 5. The maximum stem girth in case of seedlings obtained by pre-soaking on coconut water was found at 42 DAS $(1.9 \mathrm{~cm})$ at 24 hours presoaking. This can be due to giberelin in coconut water that enhanced the rate of cell division and elongation of stem portion. Increase in stem girth may be possible due to 
stimulation of cambium and it immediate cell progeny (Dhankhan and Singh, 1996).

Patil and Patil (2010) reported that auxin hormone combined with gibereline can spur growth of tissue membrane and encouraging cell division on cambium that can increasing the stem girth, so pre soaking at 24 hours can maximilized the absorbtion of phytohormon than pre soaking at 8 hours, 12 hours, 16 hours and 20 hours. Girth of stem indicate of robustness of seedlings to propping up the canopy.

Table 5. Mean performance of girth of the stem influenced by concentration and duration of seed immersion

\begin{tabular}{lcccccc}
\hline Treatment & \multicolumn{7}{c}{ Girth of the stem (cm) (DAS) } \\
& 7 & 14 & 21 & 28 & 35 & 42 \\
\hline Concentration (\%) & & & & & & \\
20 & $0.53 \mathrm{a}$ & $0.59 \mathrm{a}$ & $0.77 \mathrm{a}$ & $1.0 \mathrm{a}$ & $1.2 \mathrm{a}$ & $1.6 \mathrm{a}$ \\
40 & $0.53 \mathrm{a}$ & $0.70 \mathrm{a}$ & $0.89 \mathrm{a}$ & $1.1 \mathrm{a}$ & $1.3 \mathrm{a}$ & $1.7 \mathrm{a}$ \\
60 & $0.53 \mathrm{a}$ & $0.67 \mathrm{a}$ & $0.84 \mathrm{a}$ & $1.1 \mathrm{a}$ & $1.4 \mathrm{a}$ & $1.7 \mathrm{a}$ \\
80 & $0.55 \mathrm{a}$ & $0.66 \mathrm{a}$ & $0.82 \mathrm{a}$ & $1.1 \mathrm{a}$ & $1.4 \mathrm{a}$ & $1.7 \mathrm{a}$ \\
100 & $0.55 \mathrm{a}$ & $0.68 \mathrm{a}$ & $0.88 \mathrm{a}$ & $1.1 \mathrm{a}$ & $1.3 \mathrm{a}$ & $1.7 \mathrm{a}$ \\
\hline Duration of immersion & & & & & & \\
(hours) & & & & & & \\
8 & $0.53 \mathrm{a}$ & $0.67 \mathrm{a}$ & $0.84 \mathrm{a}$ & $1.1 \mathrm{a}$ & $1.4 \mathrm{a}$ & $1.8 \mathrm{ab}$ \\
12 & $0.54 \mathrm{a}$ & $0.62 \mathrm{a}$ & $0.86 \mathrm{a}$ & $1.03 \mathrm{a}$ & $1.2 \mathrm{a}$ & $1.5 \mathrm{c}$ \\
16 & $0.56 \mathrm{a}$ & $0.65 \mathrm{a}$ & $0.8 \mathrm{a}$ & $1.06 \mathrm{a}$ & $1.3 \mathrm{a}$ & $1.5 \mathrm{bc}$ \\
20 & $0.56 \mathrm{a}$ & $0.69 \mathrm{a}$ & $0.9 \mathrm{a}$ & $1.1 \mathrm{a}$ & $1.4 \mathrm{a}$ & $1.6 \mathrm{ab}$ \\
24 & $0.51 \mathrm{a}$ & $0.66 \mathrm{a}$ & $0.79 \mathrm{a}$ & $1.1 \mathrm{a}$ & $1.4 \mathrm{a}$ & $1.9 \mathrm{a}$ \\
\hline
\end{tabular}

DAS: Days after sowing

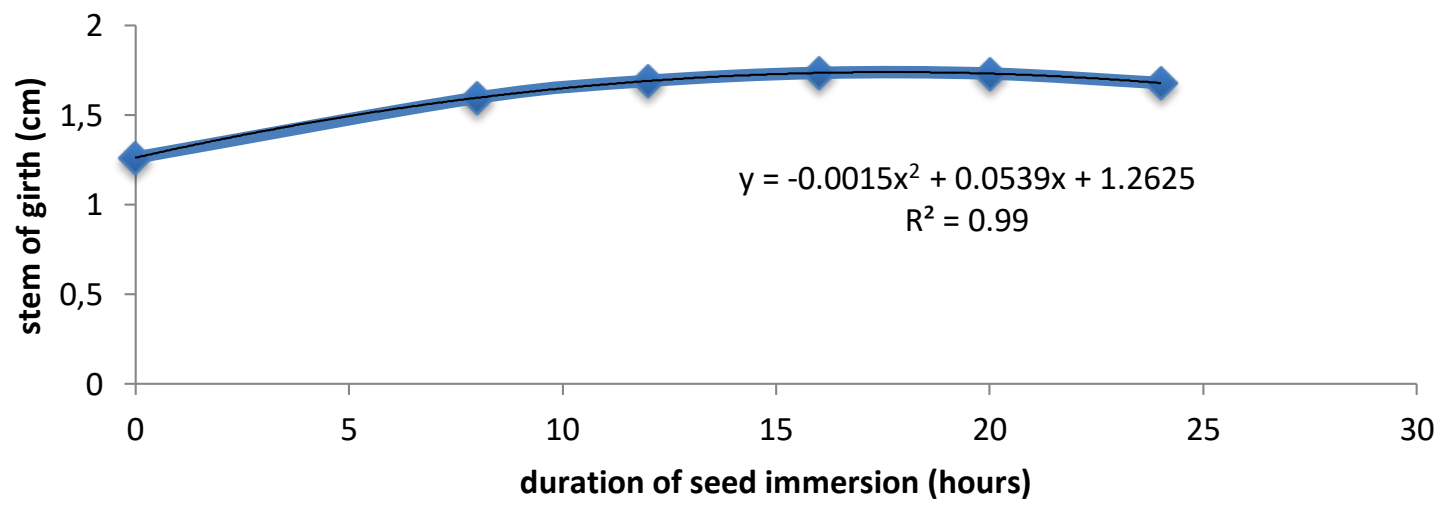

Fig 2. Relation between duration of seed immersion with stem girth at 28 DAS

Figure 2 is a further test resul using quadratic regression analysis and seen the quadratic line $Y=0,0015 X^{2}+0,0539 X+1,2625$ dan memiliki
$\mathrm{R}^{2}=99 \%$. The equation described the relation between suration of immersion and girth of stem at 28 DAS in 16 hours presoaking.

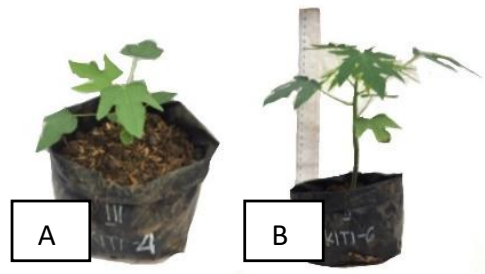

Fig 3. Growth of seedling at A) 7 DAS, B) 24 DAS

The fresh weight of shoot it was highest in seeds that treated by 8 hours presoaking with coconut water $(3.9 \mathrm{~g})$ (Table 6). Similarly the highest fresh weight of root was recorded in 8 hours presoaking $(2.5 \mathrm{~g})$ followed by 24 hours presoaking $(2.4 \mathrm{~g})$. this might be because of higher mobilization of water, nutrient uptake capacity and its transportation by gibberellin than cytokinin which has resulted into more production of photosynthetic product and translocation into various parts of the plant (Singh and Singh, 2000). Similarly, because of 
the more accumulation of photosynthetic products dry weight of shoot $(0.66 \mathrm{~g})$, dry weight of root $(0.49 \mathrm{~g})$ and total dry weight $(1.16 \mathrm{~g})$ was recorded maximum in 8 hours pre soaking.

Tabel 6. Mean performance of Fresh weight of shoot, fresh weight of root, dry weight of shoot, dry weight of root, total dry weight influenced by concentration and duration of seed immersion on seedling of papaya at 24 DAS

\begin{tabular}{llllll}
\hline Treatment & $\begin{array}{l}\text { Fresh weight } \\
\text { of shoot }(\mathrm{g})\end{array}$ & $\begin{array}{l}\text { fresh weight } \\
\text { of root }(\mathrm{g})\end{array}$ & $\begin{array}{l}\text { dry weight of } \\
\text { shoot }(\mathrm{g})\end{array}$ & $\begin{array}{l}\text { dry weight of } \\
\text { root }(\mathrm{g})\end{array}$ & $\begin{array}{l}\text { total dry } \\
\text { weight }(\mathrm{g})\end{array}$ \\
\hline $\begin{array}{l}\text { Concentration } \\
(\%)\end{array}$ & & & & \\
20 & & & & & \\
40 & $2.5 \mathrm{a}$ & $1.7 \mathrm{a}$ & $0.48 \mathrm{a}$ & $0.39 \mathrm{a}$ & $0.86 \mathrm{a}$ \\
60 & $3.1 \mathrm{a}$ & $2.2 \mathrm{a}$ & $0.49 \mathrm{a}$ & $0.4 \mathrm{a}$ & $0.89 \mathrm{a}$ \\
80 & $2.9 \mathrm{a}$ & $2.1 \mathrm{a}$ & $0.54 \mathrm{a}$ & $0.44 \mathrm{a}$ & $0.98 \mathrm{a}$ \\
100 & $3.5 \mathrm{a}$ & $2.3 \mathrm{a}$ & $0.57 \mathrm{a}$ & $0.46 \mathrm{a}$ & $1.04 \mathrm{a}$ \\
\hline $\begin{array}{l}\text { Duration of } \\
\text { immersion }\end{array}$ & $2.8 \mathrm{a}$ & $1.9 \mathrm{a}$ & $0.49 \mathrm{a}$ & $0.42 \mathrm{a}$ & $0.92 \mathrm{a}$ \\
(hours) & & & & \\
8 & & & & & \\
12 & $3.9 \mathrm{a}$ & $2.5 \mathrm{a}$ & $0.66 \mathrm{a}$ & $0.49 \mathrm{a}$ & $1.16 \mathrm{a}$ \\
16 & $2.5 \mathrm{~b}$ & $1.6 \mathrm{~b}$ & $0.42 \mathrm{c}$ & $0.31 \mathrm{c}$ & $0.73 \mathrm{a}$ \\
20 & $2.2 \mathrm{~b}$ & $1.5 \mathrm{~b}$ & $0.41 \mathrm{c}$ & $0.35 \mathrm{bc}$ & $0.76 \mathrm{bc}$ \\
24 & $3.0 \mathrm{ab}$ & $2.2 \mathrm{ab}$ & $0.51 \mathrm{bc}$ & $0.46 \mathrm{ab}$ & $0.97 \mathrm{ab}$ \\
\hline
\end{tabular}

According to Fitch (2005) the bigger biomass of a plants show the process of growth and development of the plant goes well. Increased fresh biomass of plants is also caused by good nutrient supply like macro and micro nutrient that play role in plant growth and development. Fresh weight shows the activity of plant metabolism and value of fresh weight influenced by tissue water content, nutrient and metabolism result (Tzortzakis, 2009). Fresh weight influenced by leaf size, root, stem and also the water content present in each part of the plant.

Dry weight associated with height and girth. If growth and height of the plant progress quickly then dry weight results become high. The main factor that influenced dry weight is sunlight absorbed by plant and utilization of such energy used for fixation of $\mathrm{CO} 2$. Results from the dry weight is balance between taking $\mathrm{CO} 2$ (photosynthesis) and respiration (Fitch, 2005).

\section{Conclusion}

Interaction between concentration of coconut water and duration of seed immersion can increase vigour and viability of the seeds $\mathrm{cv}$. Calina. Concentration of $60 \%$ coconut water affect on seed germination, vigour index, and speed of emergence. Concentration of coconut water not showing meaningful results for growth parameters.

Duration of immersion in 8 hours can increase seed germination, speed emergence, height of plant, number leaves of pant, stem girth, fresh weight and dry weight.

\section{References}

Directorat General of Horticulture. 2016. Fruit Productivity in Indonesia during 20112015. Ministry of Agriculture.

Statistic of Export and Import Agricultural Commodity Indonesia.2016. Export of Agricultural Commodities by Destination Country. Agricultural Statistic Database.

Desai, Amit., Trivedi, Ashwin., Panchal, Bharat., and Desai, Velji. 2017. Improvement of Papaya Seed Germination by Different Growth Regulator and Growing Media Under Net House Condition. Int.J.Curr.Microbio.App-Sci. 6(9):xx-xx.

Dhankhar DS, Singh M. 1996. Seed germination and seedling growth in aonla (Phyllanthus emblica Linn.) as influenced by Gibberellic acid and thiourea. Crop Res. 12(3):363-366.

Fitch. 2005. Carica Papaya- Papaya. Biotechnology of Fruit and Nut Crops, Vol 29. CABI, Cambridge. 174-207.

Kende, H. J. Z. 1977. The Five "Classical" Plant Hormones. Plant Cell 9 , 1197-1210.

Lay, P. 2015. Studies on Effect of Giberellic Acid ( GA3 ) and Potassium Nitrate ( KNO3 ) on Breaking of Seed Dormancy of Papaya Cv Surya. The Ecoscan 9 (1\&2). 109-133.

Matsushima, K. and Sakagami, J. 2013. Effects of Seed Hydropriming on Germination 
and Seedling Vigor During Emergence of Rice Under Different Soil Moisture Conditions. American Journal of Plant Sciences, 2013(August), Pp.1584-1593.

Nishina, M., Nagao, M. and Furutani, S. 2004. Optimizing Germination of Papaya Seeds. P.96822.

Olajide .O., Oyedeji, A.A ., Tom, G.S. and Kayode, J. (2014): Seed germination and effects of three water regimes on the growth of Dialium guineense (Wild) seedlings. American Journal of Plant Sciences. 5: 3049- 3059.

Paleg, L. 1965. Physiological Effects of Gibberellins. Annual Review of Plant Physiology. 16: 291-322.

Pandit, VIC., Nagarajan, Shanta., and Sinha, J.P. 2001. Improving Papaya (Carica papaya) Seed Germination and Seedling Growth ny Pre-sowing Treatments. Indian Journal of Agricultural Sciences. 71(11): 704-6.

Parab, Arjon Manoha., Mathad, JC., and Malshe, KV. 2017. Effect of Presoaking Chemicals on Germination and Subsequent Seedling Growth of Papaya (Carica papaya) Cv. Solo. IJCS. 5(4). 1812-1816.

Patil, P.R., and Patil, M.N. 2010. Effect of Seed Treatment with GA3 and NAA on Growth and Yield of Okra (Abmelmoschus esculentus L. Moench). 60-2. Asian Journal Horticulture.5(2): 269272.

Ramteke, V., Palthankar, D.H., Ningot, E.p., and Kurreg, V.K. 2015. Effect of GA3 and Propagation Media on Germination Growth and Vigour of Papaya Cv. Coorg Honey Dew. International Quarterly Journal of Life Science. 10(3): 1011-1016.

Shahi-Gharahlal, A., Yavari, A.R., Khayat, Mehdi., Jalali, Neda., and Farhoudi, Rosbeh. 2012. Effect of Soaking Temperature, Stratification,Potassium Nitrate and Gibberellic Acid on Seed Germination of Loquad Trees. Journal of Plant Nutrition. 35:1735-1746.

Singh, A.K., and Singh, G. 2000. Improving Germination of Papaya Seed by Potassium Nitrate, Gibberellic Acid, Potassium Chloride and Calcium Cloride in Cv. Pusa Delicious. National Seminar of Plant Physiology.

Tzortzakis, N.G. 2009. Effect of Pre-Sowing Treatment on Seed Germination and Seedling Vigour in Endive and Chicory. Horticultural Science (36). 117-125.

Victor, M., Jimenez, Mora-Newcomer., Eric, Ana Gutierrez-Sob., and Marco. 2017. Biology of the Papaya Plant Chapter 2. CIGRAS. Universidad de Costa Rica. 